\title{
DISTRIBUTION OF FALSE, INCORRECT INFORMATION, DETERMINING THE HONOR AND DIGNITY OF THE PERSON OR COMPANY UNDER THE LEGISLATION
}

\author{
Vladimir V. Yastrebov \\ Peoples' Friendship University of Russia, Moscow, Russian Federation
}

\begin{abstract}
Introduction: the company's business reputation is currently one of the main factors in doing business. The article is devoted to the study of individual issues related to the creation of a mechanism to effectively protect the business reputation of a legal entity. To this end, the author studies the legal nature of defamation under Russian law, which is directly related to business reputation, namely, its protection. Using the methods of scientific knowledge, first of all, the method of system analysis, the author determines the possibility of applying the provided defensive protection methods if false information is disseminated in relation to the bodies of a legal entity and its employees. Results:indicates that at present the concept of "business reputation" of a legal entity has a market economic (property) content, and therefore it is necessary to study the influence on it not only of defamation of the legal entity itself, but also of the governing bodies, other bodies, workers, their activities are associated with the activities of a legal entity. This is necessary for correct understanding of the essence and content of the concepts of "business reputation", "defamation", as well as for assessing the need to protect business reputation and analyzing possible ways of such protection. Findings: the author concludes that based on the peculiarities of the distribution of defamatory information regarding a legal entity, in connection with the latter doing business, such information is not only information containing allegations that a legal entity has committed the actions listed in clause 7 of Resolution of the Plenum of the Armed Forces № 3 [6], but also an indication that such actions are committed by its employees, members of government bodies.

Key words: business reputation, defamation, tort liability, market economy, business, legal entity, ways of protecting business reputation, non-pecuniary damage, non-pecuniary damage, damages, non-pecuniary benefits, distribution of defamatory information.
\end{abstract}

Citation. Yastrebov V.V. Distribution of False, Incorrect Information, Determining the Honor and Dignity of the Person or Company under the Legislation. Legal Concept, 2019, vol. 18, no. 1, pp. 137-141. (in Russian). DOI: https://doi.org/10.15688/lc.jvolsu.2019.1.19

\section{ВЛИЯНИЕ НА ДЕЛОВУЮ РЕПУТАЦИЮ ЮРИДИЧЕСКОГО ЛИЦА ДИФФАМАЦИИ, СОВЕРШЕННОЙ В ОТНОШЕНИИ НЕГО САМОГО, ОРГАНОВ УПРАВЛЕНИЯ И РАБОТНИКОВ}

\footnotetext{
Владимир Валерьевич Ястребов

Российский университет дружбы народов, г. Москва, Российская Федерация

Введение: деловая репутация компании в настоящее время является одним из главных факторов осуществления предпринимательской деятельности. Статья посвящается исследованию отдельных вопросов, связанных с созданием механизма действенной защиты деловой репугации юридического лица. С этой целью автор изучает правовую природу диффамации по российскому законодательству, которая непосредственно связана с деловой репутацией, а именно с ее защитой. С помощью методов научного познания, прежде всего, метода системного анализа, автор определяет возможность применения предусмотренных способов защиты от диффамации, если
} 
ложная информация распространена в отношении органов юридического лица и его работников. Результаты: указывается, что в настоящее время понятие «деловая репутация юридического лица» имеет рыночное экономическое (имущественное) содержание, в связи с чем необходимо исследование влияния на нее не только диффамации в отношении самого юридического лица, но и органов управления, иных органов, работников, если их деятельность ассоциируется с деятельностью юридического лица. Это необходимо для правильного уяснения сущности и содержания понятий «деловая репутация», «диффамация», а также для оценки необходимости защиты деловой репутации и анализа возможных способов такой защиты. Выводы: автором сделан вывод о том, что, исходя из особенностей распространения порочащих сведений в отношении юридического лица в связи с осуществлением последним предпринимательской деятельности, такой информацией является не только та, которая содержит утверждения о совершении юридическим лицом действий, перечисленных в п. 7 Постановления Пленума ВС РФ № 3 [6], но и указание на то, что такие действия совершают его работники, члены органов управления.

Ключевые слова: деловая репутация, диффамация, деликтная ответственность, рыночная экономика, предпринимательская деятельность, юридическое лицо, способы защиты деловой репутации, нематериальный вред, моральный вред, убытки, нематериальные блага, распространение порочащих сведений.

Цитирование. Ястребов В. В. Влияние на деловую репутацию юридического лица диффамации, совершенной в отношении него самого, органов управления и работников // Legal Concept = Правовая парадигма. -2019. - Т. 18, № 1. - C. 137-141. - DOI: https://doi.org/10.15688/lc.jvolsu.2019.1.19

\section{Введение}

Деловая репутация в условиях рыночной конкурентной экономики имеет и экономическое, и правовое содержания. В экономическом аспекте деловая репутация юридического лица традиционно рассматривается как общественное сложившееся мнение о качестве, достоинствах и недостатках работы компании не только в производственно-хозяйственном направлении, но и в сфере делового оборота и социальной ответственности [1].

До настоящего времени ни законодательство, ни правовая доктрина не пришли к единству мнения по поводу понятия и правовой природы деловой репутации юридических лиц в российском гражданском праве, ярким свидетельством чему является отсутствие легального ее определения. Судебная практика выделяет как положительную, так и отрицательную деловую репутацию юридического лица, отмечая, что «судебной защите подлежит посягательство на положительную деловую репутацию юридического лица» [4].

\section{Диффамация}

в отношении органов управления

и работников юридического лица: соотношение с диффамацией в отношении самого юридического лица

Согласно имеющемуся правовому регулированию деловая репутация относится к не- материальным благам, которые по своей сути неотчуждаемы и непередаваемы. Но в отношении деловой репутации законодателем сделано исключение, в частности, передача деловой репутации происходит в рамках договора коммерческой концессии (п. 2 ст. 1027 ГК РФ) как вклад в общее имущество простого товарищества (с. 1042 ГК РФ). Следовательно, правовая природа деловой репутации включает в себя имущественную составляющую, что позволяет говорить о ее двойственной природе.

Создание положительной деловой репутации юридического лица - это, как правило, довольно длительный процесс, предполагающий значительные усилия непосредственно исполнительных органов юридического лица, его учредителей и работников. При этом репутацию можно достаточно быстро испортить антирекламой, целенаправленной дискредитацией со стороны конкурента, и т. Д. Двойственный характер «деловой репутации» предопределял в свое время использование «компенсации морального вреда» как способа защиты в случае диффамации в отношении юридического лица. В настоящее время судебная практика заняла позицию о невозможности компенсации юридическому лицу нематериального вреда [2]. Как сказано в Обзоре ВС РФ: «Юридические лица и индивидуальные предприниматели как субъекты предпринимательской деятельности вправе защищать свою деловую репутацию путем опровержения по- 
рочащих их сведений или опубликования своего ответа в печати, а также заявлять требования о возмещении убытков, причиненных распространением таких сведений» [2].

Взыскание морального вреда (репутационного вреда) в качестве обязательного условия не предполагает предоставления доказательств о размере причиненных убытков, что обязательно при применении такой формы ответственности, как вред (убытки). Но в случае диффамации, в соответствии с п. 19 Обзора, в удовлетворении требования о возмещении убытков не может быть отказано только на том основании, что их точный размер невозможно установить. Кроме того, указано, что объективная сложность доказывания причинно-следственной связи между наличием убытков и распространением ложных и порочащих сведений, равно как и размера убытков, не должна снижать уровень правовой защищенности участников гражданского оборота при доказанности факта нарушения. Также отмечается, что по смыслу статей 15 и 393 ГК РФ при установлении причинной связи между распространением порочащих сведений и убытками необходимо учитывать, в частности, то, к каким последствиям в обычных условиях гражданского оборота могло бы привести подобное нарушение [2]. То есть, отказывая во взыскании морального вреда, репутационного вреда, законодатель в ГК устанавливает паллиативный способ на основании возмещения причиненных убытков.

Диффамация является гражданским правонарушением и влечет ответственность при соблюдении общих условий деликтной ответственности (за исключением условия о вине ответчика) [7]. Распространение порочащих юридическое лицо сведений порождает факт длительной неопределенности, причиняющей юридическому лицу значительное неудобство [5].

Главным условием наступления ответственности за диффамацию является доказанность порочащего характера информации и факта ее распространения, также должен быть установлен факт сформированной деловой репутации истца и утраты доверия к его репутации, следствием чего может быть сокращение числа клиентов и утрата конкурентоспособности [7].
Необходимо отметить, что распространение порочащих деловую репутацию сведений может быть осуществлено различными способами. В частности, юридическое лицо действует в гражданском обороте через свои исполнительные органы (ст. 53 ГК РФ), следовательно деловая репутация лиц, которые в них входят, оказывает влияние на деловую репутацию организации в целом (п. 12 Обзоpa), в виду этого действия и образ указанных лиц ассоциируются с юридическим лицом. Кроме того, репутация юридического лица отражается непосредственно на самом руководителе юридического лица [3]. Считаем необходимым распространить данное положение и на иных лиц, входящих в органы юридического лица (совет директоров (наблюдательный совет), ревизионная комиссия). В частности, как указывается в одном из судебных постановлений: «сведения, относящиеся к руководству компании, распространяются на все предприятие в целом, даже если люди, о которых идет речь, остаются неназванными, в то время как их причастность к компании четко обозначается и не вызывает сомнений. В связи с этим можно прийти к выводу, что деловая репутация члена совета директоров тесно связана с деловой репутацией организации, а посягательство на нее влечет ущемление прав организации. То же самое касается и деловой репутации исполнительного органа, так как распространенные сведения о директоре относятся к деловой репутации общества [8]. При этом из содержания данной информации должна прослеживаться безусловная связь между организацией и лицом, упомянутым в таком сообщении, их отождествление.

Судебная практика положительно решает вопрос о влиянии диффамации в отношении работника на деловую репутацию юридического лица (п. 12 Обзора) в связи с тем, что действия работника считаются действиями юридического лица, следовательно распространение ложной информации о некачественном выполнении работником своей работы повлечет возможный отток клиентов.

\section{Выводы}

Негативная деловая репутация юридического лица складывается в результате диф- 
фамации, которая вызывает у потенциальных контрагентов юридического лица не соответствующие действительности представления о финансовом состоянии последнего, о качестве производимой им продукции, совершаемой не только в отношении самого юридического лица, но и его органов (исполнительного, совета директоров, ревизионной комиссии) и работников. Должна быть установлена презумпция нарушения деловой репутации юридического лица, если из информации о недобросовестности, проявленной лицами, входящими в органы юридического лица, и работниками при выполнении производственно-хозяйственных функций, прослеживается четкая связь между указанными лицами и (или) их действиями и самим юридическим лицом.

\section{СПИСОК ЛИТЕРАТУРЫ}

1. Быкова, Ю. Н. Деловая репутация как критерий финансовой устойчивости компании : дис. ... канд. экон. наук / Быкова Юлия Николаевна. - М., 2009. $-155 \mathrm{c}$.

2. Обзор практики рассмотрения судами дел по спорам о защите чести, достоинства и деловой репутации : (утв. Президиумом Верховного Суда РФ 16.03.2016) // Бюллетень Верховного Суда РФ. 2016. - № 10 .

3. Определение Верховного Суда Российской Федерации от 26 октября 2015 г. по делу № 307-ЭС155345, А56-17708/2014. - Доступ из справ.-правовой системы «КонсультантПлюс» (дата обращения: 12.12.2018).

4. Постановление Арбитражного суда Восточно-Сибирского округа от 14 августа 2014 г. по делу № А10-3958/2013. - Доступ из справ.-правовой системы «КонсультантПлюс» (дата обращения: 12.12.2018).

5. Постановление ЕСПЧ от 06.04.2000 «Дело “Комингерсолль С.А.” (Comingersoll S.A.) против Португалии» (жалоба № 35382/97) [рус., англ.]. Электрон. текстовые дан. - Режим доступа: http:// www.echr.coe.in. - Загл. с экрана.

6. Постановление Пленума Верховного Суда РФ от 24.02.2005 № 3 «О судебной практике по делам о защите чести и достоинства граждан, а также деловой репутации граждан и юридических лиц» // Бюллетень Верховного Суда РФ. -2005. -№4.

7. Постановление Президиума ВАС РФ от 17.07.2012 № 17528/11 по делу № А45-22134/2010. Доступ из справ.-правовой системы «КонсультантПлюс» (дата обращения: 12.12.2018).
8. Постановление ФАС Уральского округа от 22 июня 2011 г. № Ф09-3347/11-С6поделу№ А60-32756/ 2010-С7. - Доступ из справ.-правовой системы «КонсультантПлюс» (дата обращения: 12.12.2018).

\section{REFERENCES}

1. Bykova Yu.N. Delovaya reputatsiya kak kriteriy finansovoy ustoychivosti kompanii: dis. ... kand. ekon. nauk [Business Reputation as a Criterion of Financial Stability of the Company. Cand. ekon. sci. diss.]. Moscow, 2009. 155 p.

2. Obzor praktiki rassmotreniya sudami del po sporam o zashchite chesti, dostoinstva i delovoy reputatsii: (utv. Prezidiumom Verkhovnogo Suda RF 16.03.2016) [Review of the Practice of Consideration by the Courts of Cases of Disputes on the Protection of Honor, Dignity and Business Reputation (approved by the Presidium of the Supreme Court of the Russian Federation on March 16, 2016)]. Biulleten Verkhovnogo Suda RF [ Bulletin of the Supreme Court of the Russian Federation], 2016, no. 10.

3. Opredelenie Verkhovnogo Suda Rossiyskoy Federatsii ot 26 oktyabrya 2015 g. po delu № 307ES15-5345, A56-17708/2014 [Determination of the Supreme Court of the Russian Federation of October 26, 2015 in Case No. 307-ES15-5345, A56-17708 / 2014]. Access from Reference Legal Sistem 'Consultant Plus' (accessed 12 December 2018).

4. Postanovlenie Arbitrazhnogo suda VostochnoSibirskogo okruga ot 14 avgusta 2014 g. po delu № A10-3958/2013 [Resolution of the Arbitration Court of the East-Siberian District of August 14, 2014 in Case No. A10-3958/2013]. Access from Reference Legal Sistem 'Consultant Plus' (accessed 12 December 2018 ).

5. Postanovlenie ESPCh ot 06.04.2000 «Delo “Komingersoll S.A." (Comingersoll S.A.) protiv Portugalii» (zhaloba № 35382/97) [Decision of the ECHR of 04.04.2000 “Case "Comingsoll SA"(Comingersoll SA) against Portugal” (Complaint No. 35382/97)]. URL: http://www.echr.coe.in.

6. Postanovlenie Plenuma Verkhovnogo Suda RF ot 24.02.2005 № 3 «O sudebnoy praktike po delam o zashchite chesti i dostoinstva grazhdan, a takzhe delovoy reputatsii grazhdan i yuridicheskikh lits» [Resolution of the Plenum of the Supreme Court of the Russian Federation of February24, 2005 No. 3 “On Judicial Practice in Cases of Protecting the Honor and Dignity of Citizens, as Well as Business Reputation of Citizens and Legal Entities"]. Byulleten Verkhovnogo Suda RF [Bulletin of the Supreme Court of the Russian Federation], 2005, no. 4.

7. Postanovlenie Prezidiuma VAS RF ot 17.07.2012 № 17528/11 po delu № A45-22134/2010 [Resolution of the Presidium of the Supreme Arbitration Court of the Russian Federation of 
B.В. Ястребов. Влияние на деловую репутацию юридического лица диффамации

17.07.2012 No. 17528/11 in Case No. A45-22134/2010]. Access from Reference Legal Sistem 'Consultant Plus'. (accessed 12 December 2018).

8. Postanovlenie FAS Uralskogo okruga ot 22 iyunya 2011 g. № F09-3347/11-S6 po delu
№ A60-32756/2010-S7 [Resolution of the Federal Antimonopoly Service of the Ural District of June 22, 2011 No. F09-3347/11-C6 in Case No. A60-32756/2010C7]. Access from Reference Legal Sistem 'Consultant Plus' (accessed 12 December 2018).

\section{Information about Author}

Vladimir V. Yastrebov, Postgraduate Student, Department of Civil Law and Process and International Private Law, Peoples' Friendship University of Russia, Miklukho-Maklaya St., 6, 117198 Moscow, Russian Federation, vladimir-soin2012@yandex.ru, https://orcid.org/0000-0003-1729-6752

\section{Информация об авторе}

Владимир Валерьевич Ястребов, аспирант кафедры гражданского права и процесса и международного частного права, Российский университет дружбы народов, ул. Миклухо-Маклая, 6, 117198 г. Москва, Российская Федерация, vladimir-soin2012@yandex.ru, https://orcid.org/ 0000-0003-1729-6752 